Contents lists available at Journal IICET

JPPI (Jurnal Penelitian Pendidikan Indonesia)

ISSN: 2502-8103 (Print) ISSN: 2477-8524 (Electronic)

\title{
Perubahan model pertukaran dalam sistem bagi hasil nelayan dan upaya peningkatan pemahaman bagi nelayan
}

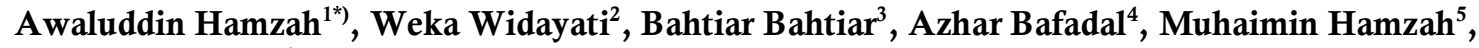 \\ Muh.Aswar Limi ${ }^{6}$ \\ ${ }^{1}$ Program Studi Penyuluhan Pertanian, Fakultas Pertanian, Universitas Halu Oleo, Indonesia \\ ${ }^{2}$ Fakultas Ilmu dan Teknologi Kebumian, Universitas Halu Oleo, Indonesia \\ ${ }^{3}$ Program Studi Sosiologi, FISIP, Universitas Halu Oleo, Indonesia \\ ${ }^{4}$ Program Studi Agribisnis, Fakultas Pertanian, Universitas Halu Oleo, Indonesia \\ ${ }^{5}$ Program Studi Budidaya Perairan, Fakultas Perikanan dan Ilmu Kelautan Universitas Halu Oleo, Indonesia \\ ${ }^{6}$ Program Studi Agribisnis, Fakultas Pertanian Universitas Halu Oleo, Indonesia
}

\section{Article Info}

\section{Article history:}

Received Aug 26 ${ }^{\text {th }}, 2021$

Revised Sept $13^{\text {th }}, 2021$

Accepted Oct $28^{\text {th }}, 2021$

\section{Keyword:}

Bagi hasil

Nelayan

Patron-klien

Model pertukaran

\begin{abstract}
Kajian tetang fenomena perbedaan sumber dan pertukaran nilai antara punggawa-sawi penting dilakukan agar tidak terjadi pemahaman berbeda tentang kelembagaan tersebut, utamanya keseimbangan bagi hasil. Tujuan Penelitian ini adalah untuk menganalisa sumber pertukaran yang dimiliki masing-masing kelompok nelayan (punggawa atau sawi) serta implikasinya pada sistem bagi hasil pada kelembagaan patron-klien nelayan di Desa Lagasa, Muna. Selain itu penelitian ini dilakukan dalam upaya untuk meningkatkan pemahaman konsep bagi nelayan mengenai perubahan model pertukaran dalam sistem bagi hasil. Penelitian menggunakan metode kualitatif. Analisis data dimulai dengan mereduksi data, dengan merangkum data yang berkaitan erat dengan kegiatan patronase nelayan. Hasil penelitian menunjukan bahwa sumberdaya yang dipertukarkan oleh seorang punggawa Desa Lagasa adalah kapal/perahu dalam berbagai jenis sesuai masa penggunaannya, alat tangkap ikan, dan uang. Kapal yang dipergunakan sebagai sarana pendukung penangkapan untuk melakukan penangkapan pada area penangkapan (fishing ground). Semakin jauh fishing ground semakin besar pula kapasitas kapal yang dibutuhkan. Sedangkan satu-satunya sumber yang dapat dipertukarkan oleh seorang sawi adalah tenaga (fisik maupun keahlian menangkap yang dimilikinya). Sawi pada umumnya bekerja di sektor penangkapan ikan karena tidak memiliki keterampilan lain.
\end{abstract}

(C) 2021 The Authors. Published by IICET

This is an open access article under the CC BY-NC-SA license

(https://creativecommons.org/licenses/by-nc-sa/4.0)

\section{Corresponding Author:}

Awaluddin Hamzah,

Universitas Halu Oleo

Email: awal.hamzah@gmail.com

\section{Pendahuluan}

Kegiatan produksi (penangkapan ikan) nelayan utamanya lapisan buruh, sebagian besar tergantung dari hubungan baik dengan pihak juragan (pemilik kapal). Keadaan tersebut sesuai temuan Hamzah, et al, (2019) bahwa keterbatasan sumber modal yang dialami oleh nelayan (nelayan buruh) memaksa mereka untuk menjalin hubungan dalam kelembagaan patron-klien. Hal tersebut dikarenakan kekurangan ataupun ketiadaan modal finansial yang memadai. Kekurangan modal tersebut semakin menambah beban dan tantangan serta persaingan yang besar dalam hal pemanfaatan sumberdaya laut. Nelayan buruh dengan kemampuan serta 
keterampilan menangkap ikan adalah potensi, disisi lain tidak adanya modal adalah kendala, mengingat wilayah laut adalah wilayah terbuka yang dapat dimanfaatkan oleh siapa saja yang memiliki kemampuan untuk mengelola sumberdaya yang ada di dalamnya.

Terwujudnya hubungan yang terjadi pada kelompok termasuk didalamya hubungan patron-klien, Blau (Ritzer, 2004) memberikan ilustrasi bahwa ketika seseorang berharap bantuan orang lain, sementara dari dirinya tidak ada sesuatu yang dapat dipertukarkan sebagai imbalannya, tersedia empat alternatif kemungkinan. Pertama, orang dapat memaksa orang lain untuk membantunya. Kedua, mencari sumberdaya lain untuk memenuhi kebutuhannya. Ketiga bersabar demi mendapat bantuan orang lain tersebut. Keempat dapat mensubordinasikan dirinya kepada orang lain sehingga dia bisa memberikan kepada orang lain semacam "hutang budi".

Asumsi kunci teori pertukaran dapat memperkuat analisa mengenai perkembangan hubungan patron klien. Asumsi tersebut menurut Haryanto (2012) adalah; (1) perilaku dimotivasi oleh keinginan untuk meningkatkan hasil dan menghindari kerugian (meningkatkan dampak positif dan mengurangi dampak negatif); (2) hubungan pertukaran pertukaran berkembang dalam struktur ketergantungan mutual baik karena adanya kesamaan alasan dari pihak yang terlibat dalam pertukaran untuk mendapatkan sumberdaya ataupun karena tidak adanya keinginan membangun jaringan hubungan pertukaran, (3) aktor yang terlibat secara timbal balik meningkatkan pertukaran dengan pasangan khusus pada kesempatan lain; (4) dampak bernilai akan mengikuti hukum ekonomi utilitas marginal yang semakin turun atau prinsip psikologi mengenai kepuasan. Dalam konteks komunitas nelayan Desa Lagasa, kelembagaan patron-klien yang ada dapat terjadi melalui hubungan antara: pengusaha (pemilik kapal) dengan nelayan buruh. Dalam kelembagaan ini terjadi hubungan yang vertikal akibat perbedaan-perbedaan status yang dimiliki antara patron dan klien. Hubungan yang vertikal akibat perbedaan status selalu menimbulkan hubungan pertukaran yang saling menguntungkan antara patron dan klien. Hubungan pertukaran tersebut berimplikasi pada proporsi bagi hasil yang diperoleh antara kedua kelompok nelayan tersebut. Hubungan pertukaran tersebut dapat ditemui pada beberapa penelitian yang menghasilkan perbedaan pendapatan bagi patron dan klien, misalnya keterbatasan sumber modal yang dialami oleh nelayan (nelayan buruh) memaksa mereka untuk menjalin hubungan dalam kelembagaan patronklien (Hamzah et al, 2019), lebih disebabkan perbedaan penguasaan sumberdaya, khususnya kekayaan (Zulkifli, 1989), maupun upaya manusia untuk bertahan hidup dalam keadaan tertentu, karena itu ia adalah bagian dari strategi adaptasi manusia (Boissevain, 1966). Dapat pula disebabkan oleh pertukaran khusus antara dua pihak yang masing-masing memang merasa perlu untuk mempunyai sekutu, yakni antara mereka yang mempunyai status, superior dengan mereka yang memiliki status inferior (Hefni M, 2009). Disamping itu, dengan adanya perubahan yang terjadi tidak semua kedua belah pihak memiliki pemahaman yang sama. Pemahaman berdasarkan hasil revisi dari taksonomi Bloom, diungkapkan oleh Anderson \& Krathwohl (2001) membagi menjadi tujuh kategori proses kognitif pemahaman diantaranya: menafsirkan (interpreting), memberikan contoh (exemplifying), mengklasifikasikan (classifying), meringkas (summarizing), menarik inferensi (inferring), membandingkan (comparing), dan menjelaskan (explaining). Upaya peningkatan pemahaman sangat penting dilakukan agar kegiatan perekonoian di daerah setempat berjalan sesuai dengan apa yang di harapkan.

\section{Metode}

Penelitian dilaksanakan pada bulan April sampai Agustus 2019, di Desa Lagasa, Kecamatan Poasia, Kota Muna Provinsi Sulawesi Tenggara. Responden penelitian dipilih secara purposive, hubungan personal antara peneliti dan calon informan (responden) sudah terjalin dengan baik sebelumnya, mayoritas masyarakatnya bekerja sebagai nelayan tangkap, serta kelembagaan sangat menonjol yakni sistem hubungan punggawa-sawi (patronklien).

Jenis penelitian ini adalah penelitian kualitatif yaitu metode penelitian yang digunakan untuk meneliti pada kondisi obyek alami, di mana peneliti adalah sebagai instrumen kunci, dengan kata lain menjelaskan fakta melalui tindakan individu. Jenis penelitian ini merupakan studi kasus yang bertujuan mengkaji secara utuh terhadap fenomena pertukaran yang berdampak pada hasil yang diperoleh antara kelompok nelayan patron (punggawa) maupun klien (sawi).

Teknik pengumpulan data yang digunakan oleh peneliti dalam memperoleh data dan informasi di antaranya meliputi observasi, wawancara, dan dokumentasi. Responden dalam penelitian ini merupakan orang atau pelaku yang benar-benar tahu dan menguasai masalah, serta terlibat langsung dengan masalah penelitian. Patron yang dipilih adalah seseorang yang melakoni posisi tersebut minimal pada 2 (dua) dekade (tahun 1980-1990, 1991-2000, atau tahun 2001- sekarang), atau menggunakan 2 (dua) atau lebih moda produksi yang berbeda. Untuk pengumpulan data kualitatif, penentuan informan didasarkan pada informasi 
awal tentang warga yang terlibat dalam kegiatan nelayan, baik sebagai nelayan buruh, nelayan tradisional, nelayan pemilik, maupun pedagang ikan. Informasi tentang hal ini terutama diharapkan dari petunjuk aparat Kelurahan atau kepala lingkungan (kepala RT). Kepada informan awal yang telah diwawancarai ditanyakan tentang warga komunitas yang dapat dijadikan informan berikutnya.

Analisis data kualitatif dilakukan secara interaktif dan berlangsung terus menerus sampai tuntas. Analisis data yang digunakan peneliti adalah analisis data model Miles Huberman yang meliputi reduksi data, display data, penarikan kesimpulan dan verifikasi (Sugiyono, 2015). Teknik pemeriksaan keabsahan data adalah derajat kepercayaan atas data penelitian yang diperoleh dan bisa dipertanggung jawabkan kebenarannya. Untuk pemeriksaan keabsahan data dalam penelitian kualitatif meliputi uji kredibilitas (credibility), uji transferabilitas (transferability), uji dependabilitas (dependability) dan terakhir uji obyektivitas (confirmability) (Sugiyono (2015).

\section{Hasil dan Pembahasan}

\section{Dinamika Kelembagaan Punggawa-Sawi}

Dalam berbagai literatur sejarah, seperti dikemukakan oleh Pelras (Salman, 2006), Putra (Suriadi,2006) bahwa masyarakat Bugis Makassar adalah masyarakat yang mempraktekkan hubungan patronase (punggawa-sawi) pada hampir semua apek kehidupannya kehidupan. Demikian pula yang terjadi pada aktivitas penangkapan ikan pada nelayan Desa Lagasa. Pada nelayan Desa Lagasa, kebersamaan dalam kelompok penangkapan menjadi sangat penting untuk menjaga keberlangsungan kelembagaan tersebut. Relevan dengan konsep diferensiasi kekuasaan Blau (Poloma, 2004; Ritzer, 2004) bahwa batasan kekuasaan sesuai dengan konsep Weberian yakni kemampuan orang atau kelompok memaksakan kehendaknya kepada pihak lain.

Oleh karena itu untuk mengkaji hal tersebut digunakan pula konsep kepatuhan (compliance) yang dikemukakan oleh Etzioni (Salman, 2006). Menurut Etzioni (Salman, 2006) kepatuhan utilitarian (utilitarian compliance), sebagai ciri hubungan pekerja-majikan pada organisasi industri dapat dilihat pada 2 (dua) dimensi, yakni dimensi kekuasaan (power) serta dimensi keterlibatan (involvement). Pihak sawi memandang bahwa punggawa adalah berperan sebagai atasan dan orang yang dipercaya dapat membantu mereka dalam hal teknis penangkapan maupun tempat bertanya dalam hal aktivitas sehari-hari.

Kelembagaan patron-klien terwujud di Kampung Bugis seiring dengan perkembangan organisasi produksi (kelompok penangkapan). Perkembangan tersebut ditandai dengan perubahan usaha penangkapan individu menjadi usaha berkelompok. Usaha nelayan ditandai dengan perubahan sarana tangkap tanpa mesin menjadi perahu menggunakan mesin. Nelayan menggunakan sarana motor tempel dan alat tangkap bagang. Usaha kelompok tersebut sudah terpisah dari rumah tangga. Pada pertengahan hingga akhir 1970 an dimulai aktivitas kelembagaan tersebut. Dalam istilah lokal,kelembagaan tersebut dikenal dengan nama punggawa-sawi.

Dari hasil wawancara dengan informan HSb dapat disimpulkan bahwa ketika penerapan bagang dengan menggunakan motor tempel, maka praktek punggawa-sawi sudah diberlakukan. Sedangkan pada teknologi gae dimulai awal tahun 1980-an, dimana organisasi produksi semakin lengkap, sehingga kelembagaan patron-klien semakin berkembang. Pada teknologi gae ukuran organisasi lebih besar disebabkan operasional penangkapan yang membutuhkan berbagai penanganan khusus.

Pada dasarnya kelembagaan patron-klien tersebut muncul seiring dengan kegiatan penangkapan dengan peralihan penggunaan sarana produksi manual menuju penggunaan sarana mesin. Penggunaan perahu sampan beralih perahu layar, perahu dengan motor tempel, dan selanjutnya pursein (gae) menyebabkan operasional membutuhkan tenaga lebih banyak. Apalagi dengan sarana tangkap yang lebih besar, lebih canggih sehingga beberapa posisi dibutuhkan untuk mendukung operasional penangkapan maupun pemasaran hasil.

Para sawi pada mulanya berperan seperti halnya pekerja terhadap atasannya. Dalam perkembangannya hubungan antara mereka tidak semata-mata murni hubungan pertukaran ekonomi, apalagi kondisi ekonomi sawi yang sangat membutuhkan keberadaan pihak penopang ekonomi bahkan sosialnya yang selanjutnya peran tersebut ditempati oleh pihak punggawa. Hal tersebut sangat penting, menurut Ritzer (Salim, 2008) bahwa penekanan tindakan dilakukan untuk mencapai tujuan-tujuan yang konsisten dengan jenjang pilihan individu. Dalam hal ini individu mempertimbangkan dua hal yang menjadi hambatan besar yakni kelangkaan sumberdaya dan kelembagaan individu. Sedangkan kelangkaan sumber menunjukkan bahwa individu memiliki akses yang berbeda terhadap sumber, ada yang mudah tetapi ada yang sukar.

Ketika hubungan patronase terutama digunakan kepada hubungan ekonomi seperti pertanian, pertambakan, penangkapan ikan, perdagangan laut, dan kerajinan, maka istilah yang digunakan nelayan 
Lagas adalah punggawa untuk patron dan sawi untuk klien. Kata punggawa disamakan dengan 'pemimpin' atau 'bos'. Istilah itu digunakan untuk menggambarkan hubungan dalam ruang lingkup yang luas antara atasan dengan bawahan yang disertai adanya ikatan pribadi.

Istilah sawi adalah pelengkap punggawa, yang bisa ditafsirkan sebagai bawahan atau orang yang memiliki hubungan pribadi dengan atasan. Menurut Pelras (Hamzah, 2009) justru karena adanya hubungan pribadi, maka punggawa kerap merujuk kepada sawi mereka sebagai anaq-anaq (anak), anaq guru (murid atau pengikut) atau tau (orang).

Seperti halnya pada daerah dengan mata pencaharian utama nelayan, hubungan punggawa-sawi terwujud saat penangkapan mengalami perubahan seiring terbentuknya kelompok-kelompok panangkapan. Artinya telah terjadi perubahan penangkapan perorangan menjadi penangkapan secara berkelompok. Perubahan tersebut bersamaan dengan pengoperasian bagan (pa'bagang), demikian pula perubahan perahu sampan menjadi perahu dilengkapi dengan motor tempel. Pola hubungan tersebut mengalami perkembangan pada saat penerapa teknologi gae. Hal tersebut ditandai pula dengan ciri bahwa manajemen produksi mulai dipisahkan dari pemilik (punggawa darat) dengan memberikan wewenang yang lebih luas kepada punggawa laut, walaupun pada umumnya punggawa laut adalah keluarga dekat atau orang kepercayaan dari punggawa darat. Ciri lainnya adalah penerapan sistem bagi hasil yang memungkinkan sawi untuk memperoleh pendapatan yang lebih dari cukup.

Hubungan antara punggawa-sawi di Lagasa pada umumnya diawali keinginan sawi untuk bergabung dalam satu armada. Keinginan tersebut sangat terkait dengan kebutuhan sumber mata pencaharian dalam memenuhi kebutuhan mereka. Walaupun hubungan tersebut dalam kerangka saling menguntungkan (simbiosis mutualisme), akan tetapi dari segi sumber pertukaran menggambarkan bahwa dalam kelembagaan tersebut tingkat kebutuhan sawi terhadap punggawa lebih besar dibanding kebutuhan punggawa terhadap sawi.

Hal tersebut tergambar dari wawancara beberapa informan punggawa bahwa untuk mendapatkan sawi dalam kegiatan penangkapan bukanlah hal yang sulit. Demikian pula hasil wawancara dengan sawi bahwa pada umumnya mereka sangat membutuhkan pekerjaan tersebut sehingga selalu berusaha bekerja dengan baik serta patuh terhadap semua keputusan yang ditetapkan oleh punggawa.

Representasi dari teori pertukaran Blau (Poloma, 2004) mendasarkan diri pada premis bahwa perilaku sosial harus dipahami sebagai sebuah pertukaran sumberdaya yang bernilai. Hal tersebut sejalan pula dengan pendapat Scott (1993) bahwa sebagai pola pertukaran yang tersebar, jasa dan barang yang dipertukarkan oleh patron dan klien mencerminkan kebutuhan yang timbul serta sumberdaya masing-masing. Bagi klien unsur kunci evaluasi adalah perbandingan antara jasa yang diterimanya dengan yang diberikannya.

Walaupun demikian, nelayan di Lagasa sangat merasakan sisi positif dari hubungan tersebut. Tanpa memandang punggawa atau sawi yang lebih besar memiliki sumberdaya, pola hubungan tersebut terus berlangsung. Representasi dari nilai siri' bagi suku Bugis sangat terlihat. Dalam konsep siri' terdapat jenis Siri' Mappakasiri'siri'. Siri' jenis ini berhubungan dengan etos kerja. Goncing (2011) mengemukakan bahwa dalam falsafah Bugis disebutkan, "narekko degaga siri'mu, inrengko siri'." Artinya, kalau anda tidak punya malu maka pinjamlah kepada orang yang masih memiliki rasa malu (siri'). Begitu pula sebaliknya, "narekko engka siri'mu, aja' mumapakasiri'-siri." Artinya, kalau anda punya malu maka jangan membuat malu (malu-maluin). Bekerjalah yang giat, agar harkat dan martabat keluarga terangkat. Jangan jadi pengemis, karena itu artinya membuat keluarga menjadi malu-malu atau malu hati.

Dengan bertambahnya kebutuhan akan penanganan khusus pada sarana gae, maka tercipta pembagian kerja (diferensiasi sosial) pada kelompok penangkapan. Pembagian kerja ditentukan oleh jenis tugas serta sawi yang dianggap mampu untuk melakoni tugas tersebut. Pembagian kerja tersebut sangat berkorelasi dengan bagi hasil yang diberlakukan. Semakin spesifik tugas dan tanggung jawab yang diberikan, semakin besar pula imbalan yang diperoleh dari bagi hasil pada hubungan produksi yang diciptakan antara punggawa terhadap sawi. Relevan dengan hal tersebut, Suseno (1999) menjelaskan bahwa hubungan-hubungan produksi itu bukan hanya ditentukan tingkat perkembangan kekuatan produksi tetapi juga ditentukan oleh tuntutan efisiensi produksi.

Seperti halnya pada masyarakat yang menjalankan praktek patronase lainnya, kelembagaan punggawa-sawi pada masyarakat nelayan Lagasa juga terjadi karena hubungan yang tidak seimbang antara 2 (dua) kelompok masyarakat tersebut menjalankan praktek etika subsistensi. Etika subsistensi memberi dasar pada berkembangnya ekonomi normatif atau moral.

Sedangkan dari pihak punggawa, menganggap sawi yang bekerja dapat berposisi sebagai pengikut. Sifat luwes dan meluas dari hubungan kerja terlihat pada asal usul hubungan yang sebelumnya terjalin melalui 
hubungan kekerabatan maupun hubungan tetangga. Hal tersebut relevan dengan teori Scott (1972) bahwa hubungan patron-klien ditandai oleh sifat luwes dan meluas. Sifat tersebut menurut Wolf (Salman, 2006) yang menyebabkan hubungan patron-klien sulit untuk dilepaskan.

Lebih lanjut dikemukakan pula bahwa hubungan tercipta bila kekuasaan (power) yang mempengaruhi kepatuhan berbasis pada remunerasi dan keterlibatan yang mendasari kepatuhan berbasis pada kalkulasi. Pada hubungan punggawa-sawi nelayan tangkap Desa Lagasa, pengaruh yang diperlakukan oleh punggawa berbasis remunerasi serta manipulasi normatif. Remunerasi dilakukan dalam bentuk bagi hasil, jame-jame, sedangkan manipulasi normatif dipraktekkan dalam bentuk pemberian bantuan yang mengikat, misalnya panjar, atau bantuan bagi keperluan sawi.

Untuk mempertahankan hubungan tersebut beberapa strategi juga dijalankan oleh punggawa. Punggawa Al (56) memiliki sebuah kapal serta sarana tangkap lain, dengan nilai investasi sebesar $\mathrm{Rp} 1,4 \mathrm{M}$ dengan kapasitas kapal 54 GT. Punggawa Al sendiri berperan sebagai punggawa darat dengan mempercayakan seorang nakhoda sebagai punggawa laut sebagai penanggung jawab operasional penangkapan sehari-hari.

Organisasi penangkapan berjumlah 25 orang termasuk nakhoda. Punggawa Al menerapkan prinsip kejujuran dan keterbukaan dalam kelompok penangkapannya. Disamping itu punggawa juga membebaskan sawi untuk memanfaatkan waktu luang di atas kapal untuk memancing ikan. Nelayan dapat memperoleh ikan hasil pancing 5-10 kg sekali trip. Dengan asumsi harga ikan rata-rata $\mathrm{Rp} 14.000,-/ \mathrm{kg}$ ketika didaratkan, nelayan mampu memperoleh penghasilan sebesar Rp 70.000-Rp 140.000, diluar bagi hasil penangkapan yang pada kapal tersebut. Ikan hasil pancing tersebut sepenuhnya hak milik sawi. Disamping itu punggawa juga memberikan bonus ikan, yang saat ini diberikan dalam bentuk uang yang besarannya berkisar Rp 100.000-Rp 250.000 sekali trip. Disamping itu, punggawa Al juga memberikan bonus dari penghasilan bersih yang diterima pada saat terjadi surplus hasil tangkapan. Besaran bonus tersebut pernah mencapai Rp 1.000.000,- per sawi.

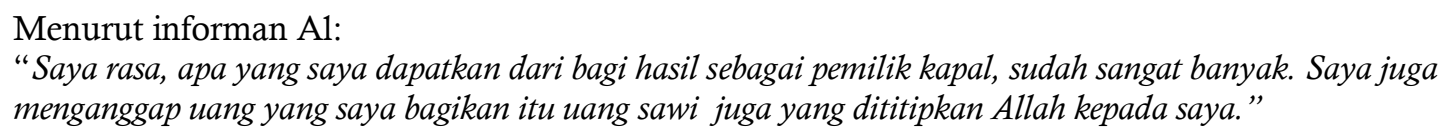

Hal serupa dilakukan oleh punggawa Ar, yang mempercayakan operasioanal penangkapan kepada anak laki-laki tertua Am (35) sebagai punggawa laut. Keseluruhan sawi diberikan panjar terlebih dahulu. Mereka juga menerapkan prinsip kejujuran, misalnya dengan memperlihatkan semua nota-nota pembelian perbekalan, biaya operasional, serta biaya lainnya kepada seluruh sawi. Punggawa juga memberikan keleluasaan pada sawi untuk memancing ikan di sela-sela aktivitas penangkapan.

Menurut punggawa, para sawi memiliki banyak waktu yang dapat digunakan untuk memancing, mengingat aktivitas melingkar sampai pada memuat hasil tangkapan hanya berlangsung dari jam 03.30 sampai jam 07.30. Jadi nelayan hanya menbutuhkan waktu 4 jam untuk melaksanakan aktivitas utama. Selain waktuwaktu tersebut sawi dapat mencari tambahan penghasilan melalui kegiatan memancing. Seperti halnya punggawa Al, Ar melakukan pembagian hasil setiap 3 bulan dengan jumlah 14-16 trip penangkapan.

Hal yang berbeda dilakukan oleh punggawa HR, HB, dan HSb dalam hal waktu pembagian hasil. Pada awalnya mereka melakukan sistem bagi hasil setiap bulannya, dengan pertimbangan bahwa pekerja/sawi harus menerima langsung hasil keringatnya. Akan tetapi mereka menerapkannya sesuai kesepakatan dengan pihak sawi, ataupun ketika hasil tangkapan dianggap melebihi target rata-rata dalam setiap trip. Sedangkan sistem pembagian hasil, bonus jame-jame serta pemberian pinjaman bagi sawi dilakukan seperti halnya punggawa lainnya. Saat ini mereka juga melaksanakan pembagian hasil tangkapan setiap 3 bulan.

Dari sistem bagi hasil yang diterapkan pada setiap 3 bulan, punggawa sebagai pemilik akan mengambil terlebih dahulu biaya operasional selama trip penangkapan. Dalam 3 bulan tersebut nelayan mampu melakukan 14-16 trip. Artinya sekali kegiatan setiap trip memakan waktu 5-6 hari. Selanjutnya punggawa berhak memperoleh 10\% dari penghasilan kotor mereka. Dana tersebut diperuntukan bagi biaya perawatan kapal dan alat tangkap. Hasil bersih tersebut selanjutnya dibagi 50\% untuk punggawa dan 50\% diperuntukkan bagi sawi, dimana $50 \%$ hasil bersih tersebut dibagi sesuai tugas dan tanggung jawab masing masing.

Dari uraian tersebut dapat disimpulkan bahwa terdapat faktor penting yang dilakukan oleh punggawa yang dapat mempertahankan hubungan patron-klien pada organisasi penangkapannya. Hal tersebut antara lain pendapatan yang memadai bagi sawi yang dapat dipergunakan untuk menutupi kebutuhan hidup sehari-hari, kejujuran dan keterbukaan yang diterapkan oleh punggawa serta pemberian bonus. Disamping itu kenyamanan dan keselamatan dalam bekerja menjadi pertimbangan pula. Oleh karena itu, bagi punggawa kondisi kapal dan alat tangkap menjadi perhatian serius. 


\section{Jenis dan Dimensi Pertukaran}

Hasil penelitian ini menemukan bahwa hubungan kelembagaan patron-klien sebagaimana dicirikan oleh Scott (Salman, 2006) ditemui di Desa Lagasa, walaupun tidak sepenuhnya memiliki ciri yang sama. Menurut hasil pengamatan dan hasil wawancara dengan informan bahwa ciri kelembagaan patron-klien di Desa Lagasa adalah; terdapatnya ketidaksamaan dalam pertukaran (inequality of exchange) yang menggambarkan perbedaan lebih dalam kekayaan dari pada kekuasaan dan kedudukan. Keterbatasan sumber modal yang dialami oleh nelayan (nelayan buruh) memaksa mereka untuk menjalin hubungan dalam kelembagaan patron-klien (punggawa-sawi) dengan orang-orang kaya (yang memiliki perahu atau kapal tonase besar dan pedagang pengumpul ikan), baik yang berasal dari Kampung Bugis maupun yang berasal dari luar. Perbedaan dalam hal kekayaan akhirnya membentuk pula perbedaan dalam hal kekuasaan dan kedudukan. Patron (punggawa), dalam kelembagaan patron-klien, karena kekayaan yang dimiliki menempatkannya pada kedudukan posisi atas dalam hubungan hirarki secara vertikal. Karena kedudukannya itu pula akhirnya sang patron memiliki kekuasaan yang lebih tinggi atas kliennya.

Sumberdaya yang dipertukarkan oleh seorang punggawa Desa Lagasa adalah kapal/perahu dalam berbagai jenis sesuai masa penggunaannya, alat tangkap ikan, dan uang. Adapun Kapal yang dipergunakan sebagai sarana pendukung penangkapan untuk melakukan penangkapan pada area penangkapan (fishing grounds). Semakin jauh fishing grounds semakin besar pula kapasitas kapal yang dibutuhkan. Kapal-kapal tersebut juga telah mengalami modifikasi sejak penangkapan tradisional dengan menggunakan perahu tanpa motor, sampai penggunaan kapal pursein yang dipergunakan oleh nelayan saat ini. Nelayan atau pemilik modal (punggawa) melakukan investasi pengadaan kapal tersebut. Alat tangkap yang digunakan juga telah mengalami modifikasi sejak penangkapan sistem penangkapan tradisional dengan menggunakan pancing, bubu, sampai penggunaan pukat cincin yang digunakan sekarang ini. Alat-alat tangkap tersebut juga diinvestasikan oleh nelayan dalam hal ini pihak punggawa.

Sumber pertukaran yang dimiliki oleh punggawa juga adalah uang. Disamping sebagai alat investasi kapal dan alat tangkap, punggawa juga biasanya memberikan bantuan atau pinjaman modal bagi sawi. Disamping itu uang tersebut kadang digunakan pula oleh sawi untuk keperluan anaknya sekolah, sakit, bangun rumah atau keperluan lainnya. Uang tersebut dipergunakan oleh sawi dengan konsekuensi perjanjian yang telah disepakati bersama, baik berkaitan dengan aktivitas penangkapan maupun diluar kegiatan penangkapan.

Menurut informan punggawa Al:

Pasti kita tidak inginkan sawi itu kerja tidak bagus karena pusing tidak punya uang. Kita juga mengerti dengan itu. Mereka juga ada anak yang sekolah, atau mau perbaiki rumahnya. Jadi ya..kita bantu

Sedangkan satu-satunya sumber yang dapat dipertukarkan oleh seorang sawi adalah tenaga (fisik maupun keahlian menangkap yang dimilikinya). Sawi pada umumnya bekerja di sektor penangkapan ikan karena tidak memiliki keterampilan lain sehingga mereka merasa tidak ada alternatif pekerjaan lain. Keterampilan yang terbatas tersebut menyebabkan sawi hanya terkonsentrasi pada satu jenis pekerjaan yang lebih banyak berhubungan dengan aktivitas fisik.

\section{Menurut sawi Ed; \\ Saya tidak sampe tamat SMA. Tidak bisa juga kerja yang lain. Paling-paling bawa ojek. Sekarang hampir semua orang punya motor jadi penumpang sepi. Kita hanya bisa ikut pagae.}

Walaupun sawi membutuhkan pekerjaan dengan bergabung pada organisasi penangkapan (organisasi produksi), akan tetapi mereka juga memiliki pertimbangan dalam memilih patron (punggawa) dalam bekerja. Beberapa pendapat yang dikemukakan oleh informan sawi disimpulkan bahwa seorang sawi akan memilih punggawa dengan beberapa pertimbangan yakni mampu menyediakan/memenuhi kebutuhan utamanya (subsisten), memiliki hubungan keluarga, kerabat atau tetangga serta jujur.

Seorang sawi Ed menuturkan:

Ada banyak (beberapa) pemilik kapal (punggawa) bisa kita bekerja. Kita pilih karena kita anggap mereka jujur, kalau bagi hasil yang adil. Kita juga masuk kesitu (memilih punggawa) karena supaya kita bisa hidup. Saya ikut karena yang punya kapal itu termasuk kakek saya. Teman-teman lain juga pasti begitu.

Terpenuhinya kebutuhan pokok menjadi pertimbangan utama sawi untuk bekerja pada satu kelompok penangkapan. Kebutuhan tersebut diperoleh dengan melakukan hubungan pertukaran melalui sistem penangkapan yang memberlakukan pola hubungan punggawa-sawi tersebut. Pola hubungan tersebut memungkinkan sawi untuk memperoleh penghasilan dalam masa tertentu dari sistem imbalan dalam hal ini bagi hasil yang diterapkan. Dengan penghasilan tersebut, nelayan mampu membeli bahan kebutuhan subsisten. 
Keadaan tersebut sesuai dengan apa yang dikemukakan oleh Blau (Poloma, 2004) mengenai strukturalisme pertukaran bahwa ada 2 prasyarat perilaku yang menjurus pada pertukaran sosial yakni; perilaku tersebut berorientasi pada tujuan-tujuan yang hanya dicapai melalui interaksi dengan orangn lain, perilaku harus bertujuan untuk memperoleh sarana bagi pencapaian tujuan-tujuan tersebut. Tujuan yang diinginkan dapat berupa ganjaran ekstrinsik (uang, barang, jasa) bisa juga ganjaran intrisik (kehormatan, termasuk kasih sayang).

Sejalan dengan hal tersebut, Simola (2014) mengemukakan bahwa ada tiga faktor utama terjadi pada diri seorang punggawa yaitu (1) status sosial, (2) kepemilikan dan (3) kepribadian seorang ponggawa terhadap sawinya. Walaupun demikian Ed juga menuturkan bahwa kepatuhan mereka terhadap punggawa lebih disebabkan oleh ketergantungan yang tinggi terhadap sumber mata pencaharian.

Perbedaan sumber daya yang dapat dipertukarkan tersebut lebih banyak diperankan dalam konteks aktivitas penangkapan. Pada awalnya hubungan tersebut juga menekankan ascribed status (geneologis, tokoh masyarakat, bangsawan) seorang punggawa. Keadaan serupa dialami salah seorang paman dari Ed yang pernah berprofesi sebagai sawi, akan tetapi saat ini telah meninggalkan profesi tersebut. Bahkan pada masa penggunaan sarana perahu motor tempel seorang punggawa dapat diposisikan sama dengan orang tua mereka. Seorang punggawa dapat memanfaatkan jasa sawi setelah aktivitas penangkapan ikan. Sedangkan seorang sawi tidak akan menolak untuk mengikuti apa yang diinginkan oleh punggawa.

Berkembangnya hubungan patron-klien antara punggawa dan sawi tersebut berimplikasi pula munculnya hubungan-hubungan ekonomis rasional, misalnya hubungan hutang piutang. Hutang piutang tersebut menimbulkan perasaan "kurang nyaman" bagi sawi untuk pindah pada kelompok pagae dengan punggawa lain. Seperti diutarakan oleh informan sawi S1 bahwa "Saya pernah punya utang sama punggawa, jadi tidak enak mau ganti-ganti kapal untuk kerja. "Dalam teori pertukaran, Blau (Poloma, 2004) memulai tesisnya dengan menerima prinsip-prinsip dan fenomena daya tarik individu dan keinginan berbagi jenis ganjaran sosial. Keinginan untuk memperoleh ganjaran sosial merupakan sesuatu yang bersifat given dan mengharapkan ganjaran yang bersifat intrinsik maupun ekstrinsik

Walaupun demikian terkadang punggawa tidak memperhatikan perbandingan jumlah kecukupan sawi dalam organisasi produksi, dalam arti pembatasan jumlahnya tidak terlalu ketat. Dalam sekali trip terkadang sawi mencapai 25 orang, walaupun 20 orang sudah cukup untuk kegiatan penangkapan tersebut. Menurut informan (HS, Ar, Al) hal tersebut diterapkan karena keyakinan berbagi mendatangkan rezeki yang lebih banyak juga. Hal tersebut menunjukan semangat kebersamaan (norma kebersamaan) yang tinggi diantara nelayan, yang oleh Scott (1972) memberi istilah dengan etika subsistensi lokal.

Deskripsi mengenai kelembagaan punggawa-sawi sebelum penggunaan sarana produksi modern gae adalah sebagai berikut: Seorang pemilik sampan yang mempekerjakan beberapa pengikut tidak membuat ikatan perjanjian kerja yang mengikat. Pemilik perahu tidak menyediakan pancing sehingga sawi menyediakan sendiri pancing tersebut. Sistem bagi hasil yang berlaku adalah dengan sistem setoran tetap ataupun dengan sistem 50 : 50. Pengikut diwajibkan menyetor setengah dari hasil tangkapannya kepada punggawa baik dalam bentuk uang maupun ikan. Sistem tersebut dilakukan dan tidak memberatkan karena hasil tangkap yang fluktuatif bergantung musim, cuaca maupun kondisi fisik nelayan itu sendiri. Sedangkan sistem setoran mewajibkan pengikut menyetor sejumlah ikan maupun uang hasil penjualan kepada pemilik (punggawa).

Berikut hasil wawancara dengan informan sawi Lm:

"Waktu masih di kampung lama, saya kerja ikut perahu. Kita bawa pancing sendiri karena tidak disediakan. Ikan yang ditangkap sebagian kita setor. Atau bisa juga setelah dijual uangnya dibagi dua, satu bagian buat saya satu bagian buat dia. Kalau sistem setoran berat, karena belum tentu kita dapat ikan banyak dalam satu hari".

Pemilik perahu juga lebih senang dengan sistem bagi hasil 50 : 50 tersebut. Mereka khawatir kalau memberlakukan sistem setoran akan memberatkan sehingga tidak mau lagi bekerja pada perahu yang disediakan. Hal tersebut bisa membuat pemilik perahu harus turun melaut sendiri ataupun tidak memperoleh apa-apa ketika tidak melaut.

Pada periode ini, pendapatan nelayan masih terbatas pada kebutuhan subsistensi, dengan volume tangkapan yang masih terbatas dan hampir terjadi pada seluruh nelayan dimanapun yang masih menggunakan sarana produksi sederhana. Keterbatasan volume tangkapan tersebut menyebabkan nelayan tidak mampu melakukan investasi pada sarana produksi tersebut. Hal tersebut diakibatkan karena keterbatasan volume penangkapan berdampak pada berkurangnya pendapatan.

Hasil wawancara dengan salah seorang informan menguatkan kekhawatiran akan berhentinya pengikut bekerja atapun beralih pada pemilik perahu lainnya dikemukakan oleh punggawa Ar (58): 


\begin{abstract}
"Kalau mereka sampe pindah pada perahu lain karena tidak mampu kasih setoran, kita jadi rugi. Waktu itu saya bawa sampan sama 2 orang yang ikut. Jadi saya bisa dapat setengah mereka dan hasil yang saya dapat sendiri. Kalau mereka tidak kerja berarti saya hanya dapat ikan yang saya pancing sendiri. Kalau saya lihat tangkapannya sedikit saya juga hanya ambil sedikit tidak sampe setengahnya".
\end{abstract}

Pola hubungan produksi saat itu tidak menunjukkan sifat eksploitatif oleh pemilik sarana produksi (punggawa). Pola hubungan patron-klien tersebut sesuai dengan etika dasar subsistensi Scott (1992) bahwa petani menganut asas pemerataan dengan pengertian membagi sama rata apa yang terdapat di desa karena mereka percaya pada hak moral petani untuk dapat hidup secara cukup.

\title{
Struktur Sosial
}

Aktivitas penangkapan dan bongkar muat hasil tangkapan sangat dipengaruhi oleh keberadaan ABK (sawi). Sawi tersebut menjadi kelengkapan utama aktivitas penangkapan, dengan berbagai posisi serta tugas yang ada. Perekrutan sawi oleh pemilik kapal dilakukan berdasarkan kuatnya struktur komunal tradisi Bugis Makassar. Mereka direkrut berdasarkan hubungan keluarga, serta tetangga, namun tidak mengesampingkan syarat kemampuan individu untuk melaut. Dapat disimpulkan bahwa hubungan patron-klien masih bersifat egaliter. Sifat kerja pengikut adalah pekerja bebas tanpa ikatan kerja tetap dengan pemilik perahu, akan tetapi perbedaan status kepemilikan sarana produksi penangkapan membuat pengikut tetap menaruh hormat kepada pemilik perahu. Struktur sosial masyarakat pada masa subsisten membentuk struktur masyarakat komunal. Menurut Hoult ciri masyarakat komunal adalah masih rendahnya pembagian kerja, menonjolnya hubungan primer dan kuatnya ikatan pada tradisi (Amaludin, 1985).

Posisi kelembagaan kerja hanya terdiri dari dua jenis yakni seorang punggawa sebagai pemilik perahu bertindak sebagai juru mudi serta satu atau dua orang pengikut sebagai sawi, yang biasanya merupakan anak atau kerabat pemilik perahu. Posisi tersebut terbentuk karena diferensiasi yang beragam dalam kegiatan penangkapan belum dibutuhkan. Untuk dimensi jenis lapisan sebagai bagian dari stratifikasi yang ada hanya mencakup lapisan atas yang ditempati oleh posisi pemilik perahu pada level kelompok nelayan. Sedangkan pada konteks komunitas, lapisan atas terdapat kelompok bangsawan disamping posisi pemilik perahu. Masyarakat masih menempatkan individu dengan status bangsawan pada lapisan atas.

Pada dimensi sistem bagi hasil, setengah hasil tangkapan (50\%) diserahkan kepada pemilik yakni setengah jumlah ikan yang diperoleh maupun sejumlah uang setengah dari hasil penjualan keseluruhan. Tidak ada target tangkapan dalam sehari yang diberikan oleh pemilik perahu, sehingga dapat dikatakan bahwa pola hubungan non eksploitatif antara anggota dalam kelompok penangkapan. Selanjutnya perubahan sosiologis nelayan terjadi akibat penggunaan sarana motor tempel mengiringi cara produksi baru yang menggantikan cara produksi sampan. Kebutuhan akan posisi tukang bersih perahu dalam kelembagaan kerja sangat penting sebagai penambahan pembagian kerja (diferensiasi). Sawi yang sementara bekerja menangkap ikan tidak akan terganggu dengan kondisi perahu yang mudah dimasuki air atau kotoran.

Hal tersebut menguatkan pula tesis Smelser (Suwarsono dan So, 2000) tentang pembentukan lembaga baru yang menyediakan tugas tertentu untuk menjalankan tugas lebih efektif dan efisien. Pembentukan spesifikasi kerja sebagai tukang bersih air adalah dampak dari perubahan teknologi perahu itu sendiri. Menurut punggawa HSb pada mulanya sawi yang dianggap mampu menjalankan berbagai posisi kerja langsung ditugaskan, akan tetapi lama-kelamaan posisi-posisi kerja tersebut mengharuskan sawi berusaha untuk mencapai posisi tersebut. Kepatuhan terhadap punggawa bagi sawi maupun tukang bersih air bukan hanya karena status kepemilikan perahu bagi punggawa, akan tetapi punggawa dengan statusnya juga sebagai juru mudi memiliki wewenang menentukan waktu dan wilayah penangkapan. Hal tersebut disebabkan pengetahuannya sebagai juru mudi tidak diragukan lagi (wawancara dengan informan mantan punggawa).

Hasil penangkapan dijual melalui pelelangan ikan (PPI Muna sekarang). Sistem bagi hasil yang diterapkan yakni terlebih dahulu dilakukan potong tengah yakni penghitungan biaya bahan bakar, perbekalan dan perbaikan serta retribusi penjualan pada PPI, selanjutnya hasil tangkapan dibagi 2 bagian. Pemilik bertindak sebagai punggawa memperoleh 1 bagian, sedangkan 1 bagian lainnya menjadi hak sawi. Sedangkan punggawa karena posisinya sebagai juru mudi memperoleh tambahan satu (1) bagian.

Sistem bagi hasil telah menjadi pranata dalam kehidupan nelayan, namun setiap kali ada sawi yang akan bergabung dalam armada motor tempel, sistem tersebut tetap dibicarakan bersama. Bagi hasil yang diatur oleh punggawa dilakukan di rumahnya atau tempat lain yang ditentukan oleh punggawa, namun tidak pernah terjadi manipulasi ataupun pembagian yang tidak adil. Menurut punggawa HSb sistem bagi hasil tersebut disampaikan kepada seluruh sawi. Penyampaian tersebut diharapkan dapat mengurangi kecurigaan antara kedua belah pihak dalam hal pengelolaan hasil tangkapan. Hal yang sama juga terjadi saat HSb bekerja sebagai sawi kapal milik pengusaha keturunan Cina. 
Disamping itu pemberian bonus ikan (jame-jame) sudah mulai diberlakukan kepada sawi. Bonus ikan tersebut diperuntukkan sebagai lauk keluarganya. Untuk lauk sehari bonus tersebut dinilai lebih dari cukup apalagi saat hasil tangkapan yang signifikan, sehingga para sawi bisa menjual bonus tersebut setelah diambil sebagai lauk keluarga (jame-jame dalam istilah Jawa: lawuhan). Pemberian bonus ikan tersebut sangat disenangi oleh sawi. Salah seorang sawi Bc (49) mengungkapkan:

"Jame-jame yang didapat kita jual di pelelangan. Hasil yang dijual kita bisa beli rokok atau kebutuhan lainnya. Jame-jame tidak mungkin habis kita makan satu hari. Jadi sisanya kita jual dan selalu ada yang beli. Jame itu bikin kita sawi senang untuk bekerja ".

\section{Makna Patron-Klien}

Hubungan punggawa-sawi juga dapat dianalisa melalui pemaknaan posisi masing-masing serta pemaknaan terhadap posisi lainnya. Untuk maksud tersebut beberapa punggawa memaknai dirinya dalam posisi pemilik modal. Hal tersebut didasari oleh pertimbangan besarnya modal yang harus diinvestasikan pada sarana penangkapan tersebut. Sebagai pemilik modal, punggawa adalah pimpinan perusahaan. Punggawa berhak menentukan berapa trip penangkapan dalam sebulan, menerima dan memecat sawi sesuai kinerjanya, bahkan berhak menentukan besaran bagi hasil serta bonus lainnya, serta biaya operasional. Walaupun setiap pembagian hasil, sawi diperlihatkan nota-nota pembelian, akan tetapi mereka tidak pernah memperhatikan dengan cermat, protes/komplain apalagi melakukan perlawanan. Hal ini menguatkan pendapat Scott (1992) bahwa kaum miskin mendahulukan selamat, menghindari resiko sanksi yang bisa membuat kaum kaya mencabut fasilitas-fasilitas konsumsi yang sudah didapatkan.

Pemaknaan tersebut menguatkan dominasi punggawa sehingga ketergantungan sawi sangat tinggi. Menurut punggawa Al, HSb, dan Ar investasi yang mereka keluarkan sangat besar sehingga wajar jika mereka mendominasi baik keputusan maupun bagi hasil yang lebih besar dibanding sawi. Apalagi hasil tangkapan yang fluktuatif serta faktor resiko yang mengancam, maka punggawa menerapkan manajemen yang ketat dalam hal keuangan. Walaupun demikian tidak terjadi keharmonisan semu antar nelayan seperti hasil penelitian Siswanto (2008) pada nelayan Prigi, ataupun Satria (2001) mengenai sistem bagi hasil nelayan pada juragan yang berasal dar Bagan Siapi-api.

Pemaknaan lainnya adalah bahwa punggawa menganggap diri sebagai manusia biasa yang pastinya membutuhkan orang/pihak lain dalam menjalankan aktivitasnya. Walaupun dengan posisi mendominasi, sawi tetap dianggap sebagai mitra kerja. Pemaknaan tersebut antara lain menjadi alasan punggawa untuk menerapkan bagi hasil yang adil, pemberian bonus, serta memberi kebebasan memancing dan menjadi sepenuhnya hak milik sawi di sela-sela aktivitas penangkapan. Pemaknaan seperti ini relevan dengan tesis Weber (2006) bahwa sistem kerja dinasti bercorak patrimonial di mana ketaatan seorang pejabat publik bukan pada pekerjaan melainkan pada personalitas tokoh-tokoh politik (patron). Gagasan Weber tersebut adalah cara kerja ini harus digantikan dengan yang lebih rasional, di mana ketaatan kepada personal harus digantikan dengan ketaatan atas peraturan impersonal. Organisasi yang diajukan Weber adalah organisasi legal-rasional.

Dari kedua pemaknaan tersebut, dapat disimpulkan bahwa kecenderungan punggawa untuk tetap mempertahankan pola hubungan, disebabkan karena perannya yang mendominasi kegiatan penangkapan serta keuntungan yang signifikan dari investasi yang dikeluarkan. Bagi mereka posisi punggawa selain peran bisnis, juga dapat membantu ekonomi orang yang membutuhkan pencaharian. Sistem hubungan antara pekerja dan yang dipekerjakan diperankan oleh kedua pihak disamping itu juga dengan mempertahankan nilai-nilai kemanusiaan.

Sedangkan bagi pihak sawi pemaknaan tersebut juga mencakup posisi mereka sebagai tenaga kerja yang bekerja pada usaha yang dipimpin oleh punggawa. Kesimpulan hasil wawancara dengan sawi Md, Ed dan Li bahwa mereka sangat bersyukur dapat diterima bekerja pada armada gae sekarang ini. Pendapatan yang signifikan diperoleh menjadi salah satu alasan bahwa mereka merasa nyaman untuk tetap bekerja sebagai pagae. Pendapat tersebut menguatkan pendapat Scott (1992) bahwa klien adalah "milik" patron yang menyediakan tenaga dan keahliannya untuk kepentingan patron apa pun bentuknya.

Dengan pendapatan yang signifikan karena tersedianya lapangan pekerjaan, serta kesempatan sawi untuk berpindah status (mobilitas sosial) maka sawi pun ingin tetap mempertahankan hubungan tersebut. Kesempatan untuk mendorong terjadinya mobilitas sosial sangat terkait dengan hadirnya cara produksi baru. Seperti telah dijelaskan bahwa hadirnya kapal pursein (gae) menciptakan posisi kerja yang membutuhkan keahlian khusus, misalnya nakhoda, tukang batu, palampu,pakurung, pakacca yang secara langsung berdampak pada meningkatnya imbalan/bagi hasil dibanding jika mereka hanya sebagai sawi biasa. Walaupun berbagai kajian menyimpulkan telah terjadi eksploitasi pihak klien oleh pihak patron dalam hal penangkapan. Kajian tersebut antara lain Mappawata (Hamzah, 2008), Mochtaria (Satria, 2001). Pada prinsipnya, baik punggawa 
maupun sawi menyadari bahwa mereka saling bergantung dan saling membutuhkan dalam aktivitas ekonomi mereka. Secara umum sawi tidak merasa bahwa pola hubungan yang terjalin bersifat eksploitatif bagi mereka.

\section{Simpulan}

Dari berbagai uraian tersebut secara singkat proses terwujudnya kelembagaan punggawa-sawi pada nelayan Desa Lagasa dapat dikemukakan bahwa kelembagaan diawali keinginan untuk mempertahankan hidup/mata pencaharian, dengan peralihan dari unit usaha individu menjadi usaha berkelompok. Hal tersebut ditandai dengan peralihan penggunaan sarana tanpa mesin menjadi sarana yang dilengkapi mesin. Stimuli tersebut mendukung etos kerja nelayan Bugis yang terkenal mobilitas serta inovasi dalam hal pemenuhan kebutuhan hidup mereka. Inovasi tersebut berkaitan dengan peningkatan produksi, efektivitas serta efisiensi pekerjaan. Perbedaan sumberdaya yang dimiliki oleh patron (punggawa) dan klien (sawi) menyebabkan mereka bersama dalam kelembagaan patron-klien yang saling melangkapi. Patron dengan sumberdaya kapal dan alat tangkapnya serta uang, sementara klien dengan sumberdaya tenaga (fisik) untuk menunjang aktifitas penangkapan sampai pemasaran hasil tangkapan. Dinamika perkembangan kelembagaan tersebut mengikuti perkembangan teknologi penangkapan yang dapat berubah tergantung kreativitas dan inovasi nelayan. Berbagai pihak saat ini masih menganggap bahwa eksistensi patron-klien (punggawa-sawi) sebagai penghambat pengembangan masyarakat nelayan. Hal tersebut antara lain disebabkan oleh masih kuatnya pandangan negatif bahwa patron membebani nelayan. Anggapan tersebut sangat berbeda dengan persepsi sawi terhadap sistem tersebut. Hubungan punggawa-sawi justru merupakan suatu institusi yang sangat penting untuk menunjang kelangsungan kegiatan ekonomi setempat. Dalam posisi yang lain, patron (punggawa) dapat diminta masukan atau pendapat, sebagai pengawas program pengembangan masyarakat nelayan. Dalam upaya peningkatan pemahaman konsep bagi nelayan maka perlu dilaksanakannya pelatihan atau workshop mengenai model pertukaran dalam sistem bagi hasil. Hal ini dilakukan agar kelangsungan kegiatan ekonomi setempat dapat berjalan dengan lancar dan baik.

\section{Referensi}

Ansyari, I., Harsasto, P., \& Fitriyah, F. (2019). Analisis Patron Klien Terhadap Kemenangan Partai Golkar Kabupaten Tanah Datar Sejak Reformasi. Indonesian Journal of Religion and Society, 1(1), 12-23.

Arief, A. 2015. Pemberdayaan Masyarakat Nelayan Melalui Pendekatan Kelembagaan Lokal (Studi Kasus Desa Pajukukang Kecamatan Maros Utara, Kabupaten Maros). ttps://www.scribd.com

Arifin, A 2014. The Patron-Client Relation In Fishermen Community. International Journal of Academic Research . May 2014, Vol. 6 Issue 3

Gunawan,I.2013. Metode Penelitian Kualitatif, Teori dan Praktik. Jakarta Bumi Aksara. 15.

Hakim, M. 2016. Social Structure and Poverty in the Fishing Community at Pandang-Pandang, Jeneponto in South Sulawesi Province. Mediterranean Journal of Social Sciences MCSER Publishing, Rome-Italy. $7(1)$

Hamzah, A. 2008. Respons Komunitas Nelayan Terhadap Modernisasi Perikanan. Tesis IPB. Bogor

Hamzah, A. 2009. Perubahan Struktur Sosial Nelayan Akibat Modernisasi Perikanan. Jurnal Agrisep. Vol $19 / 3 / 2009$

Hamzah, A. 2013. Transformasi Moda Produksi (Mode Of Production) Masyarakat Pesisir (Studi Kasus Nelayan Bajo di Desa Latawe Kabupaten Muna Provinsi Sulawesi Tenggara). Jurnal Agriplus, 23(3): 65-72

Hamzah, A, M.Aswar., La Nalefo, A.Gafaruddin. 2015. Fishing Technology Conversion, Differentiation, And Social Mobility Of Fisherman In Lagasa Village Of Muna Regency. IJSTAS Vol: 2/1; 77-88

Hamzah, A, W. Widayati, Bahtiar., A. Bafadal. 2016. Dynamics of Institutional Patron - Client in Desa Lagasa District of Poasia Muna. Journal WWJMRD 2015; 2(8)

Hamzah, A, H.Batoa, A Gafaruddin, LK Arif, 2019. The Dynamics of Institutional Patron-Client of Fishing Community._Global Journal Of Engineering Science And Researches.6(1)

Harini, 2012. Dari Miyang Ke Longlenan: Pengaruh Jaringan Sosial Pada Transformasi Masyarakat Nelayan. Jurnal Komunitas, 4 (2) (2012)

Haryanto, 2012. Spektrum Teori Sosia. Dari Klasik Hingga Postmodern. Jakarta: Ar-Ruzz Media.

Hutagalung, M. A. K. (2019). Pengaruh kualitas pelayanan dan bagi hasil terhadap minat masyarakat menjadi nasabah bank syari'ah. Jurnal Al-Qasd Islamic Economic Alternative, 1(2), 228-239.

Imaniar, A., \& Brata, N. T. (2020). Relasi Patron-Klien di antara Tengkulak dan Petani Salak dengan Dampak Sosialnya di Banjarnegara. Solidarity: Journal of Education, Society and Culture, 9(1), 837-847.

Kusumastuti, A. (2015). Modal Sosial dan Mekanisme Adaptasi Masyarakat Pedesaan dalam Pengelolaan dan Pembangunan Insfrastruktur. MASYARAKAT: Jurnal Sosiologi, 20(1), 81-97 
Malik, M. K., Wahyuni, S., \& Widodo, J. (2018). Sistem bagi hasil petani penyakap di desa krai kecamatan yosowilangun kabupaten lumajang. JURNAL PENDIDIKAN EKONOMI: Jurnal Ilmiah Ilmu Pendidikan, Ilmu Ekonomi Dan Ilmu Sosial, 12(1), 26-32.

Minaro, S, GN. Ferero, H. Reuter, I. Puten.2016. The role of patron-client relations on the fishing behavior of artisanal fishermen in the Spermonde Archipelago (Indonesia). DOI:10.1016/J.MARPOL.2016.04.006

Mirajiani, E.S Wahyuni, A Satria, Saharuddin, T.Kusumastanto. 2014. Transformasi Pranata Patronase Masyarakat Nelayan: Dari Ekonomi Moralitas Menuju Ekonomi Pasar. Jurnal Komunitas 6 (1) DOI:10.15294/komunitas.v6i1.2950

Muazzin, Hak Masyarakat Adat atas Sumber Daya Alam: Perspektif Hukum Internasional, Padjadjaran Jurnal Ilmu Hukum, Volume 1-No. 2- Tahun 2014.

Ramadhan, G. (2020). Pilkada Bekasi Dalam Dilema Patron Klien: Antara Sosiologi Politik Dan Pemilih Rasional. Journal of Social Politics and Governance (JSPG), 2(1), 18-31.

Ransel, D. L. (2018). Character and style of patron-client relations in Russia. In Klientelsysteme im Europa der frühen Neuzeit (pp. 211-232). Oldenbourg Wissenschaftsverlag.

Risal, T., \& Alexander, A. (2019). Pengaruh persepsi bagi hasil, promosi dan kualitas pelayanan terhadap minat penggunaan jasa perbankan syariah tabungan mudharabah pada mahasiswa universitas potensi utama. Jurnal Samudra Ekonomika, 3(2), 118-130.

Salman, D. 2006. Jagad Maritim. Dialektika Modernitas dan Artikulasi Kapitalisme pada Komunitas Konjo Pesisir di Sulawesi Selatan. Makassar: Ininnawa.

Subair, Lala M. K, Sadiwibowo, B Pranowo, 2014. Resilensi Komuitas dalam Merespon Perubahan Iklim Melalui Strategi Nafkah (Studi Kasus Desa Nelayan di Pulau Ambon Maluku. Jurnal Sosial Ekonomi Kelautan dan Perikanan, 9(1): 77-90

Sulaiman, Prospek Hukum Adat Laut dalam Pengelolaan Perikanan di Kabupaten Pidie Jaya Provinsi Aceh, Jurnal Yustisia Edisi 87 September-Desember 2013

Syaputra, A., \& Jonyanis, J. (2018). Hubungan Sosial Patron Klien antara Tauke Sawit dan Petani Sawit di Desa Menggala Teladankecamatan Tanah Putih Kabupaten Rokan Hilir (Doctoral dissertation, Riau University).

Yunus, A, D Salman, E Demmallino, NM Viantika, 2016._Sociotechnical Change and Institutional Adjustment in PaddyvRice Farming During Post Green Revolution in Indonesia ._International Journal of Agriculture System (IJAS). 4(1): 218-227

Wulandari, F. (2019). Efektivitas pemanfaatan dana bagi hasil cukai hasil tembakau dalam bidang kesehatan di Kota Surakarta tahun 2018.

Hamzah, A., et al. (2020). "Perubahan Dimensi Pertukaran Dalam Sistem Bagi Hasil Setiap Periode Penggunaan Teknologi Penangkapan Ikan " Gijers 1(7). 